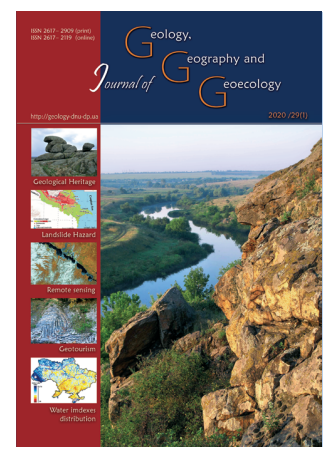

Journal of Geology.

Oresta Y. Bordun, Pavlo V. Romaniv, Wolodymyr R. Monasryrskyy

Journal home page: geology-dnu-dp.ua

Journ.Geol.Geograph.

Geology,

29(2), 233-242.

doi: $10.15421 / 112021$

\title{
Tourism geography: functional structure and role in tourismology
}

\author{
Oresta Y. Bordun, Pavlo V. Romaniv, Wolodymyr R. Monasryrskyy
}

Ivan Franko National University of Lviv,Lviv, Ukraine, obordun@ukr.net

Received: 09.12.2019

Received in revised form: 21.03 .2020

Accepted: 23.04.2020

\begin{abstract}
The objective basis of tourism as a phenomenon of social life makes it a complex, multi-faceted object of scientific knowledge. Geography was one of the sciences that has studied tourism since it became a phenomenon of human existence and has initiated an innovatory scientific direction, that is tourism geography. We researched the theoretical approaches to the definition of the notion tourism geography, tourism studies and
\end{abstract} tourismology as integral notions in the scientific discourse regarding the study and research on tourism. We determined the main legal, organizational, natural, socio-economic, humanitarian and other basics of the geography of tourism which are orientated at provision of dynamic development in the sphere in general. Modern traditions and tendencies of the European school of tourism studies, novel scientific orientations in the block of adjacent disciplines were evaluated and the authors' interpretation of the functional structure of the direction "Tourism geography" are presented. We determined the integral character of the theory of tourism geography with its characteristic structural changes due to the multi-functionality of scientific directions, because tourism geography is a complex naturalecological-socio-economic system which covers geographical, ecological, socio-cultural, economic, political, organization-legal and other aspects, processes and phenomena is related to comfortable and safe recreation. The position of tourism geography in the system of sciences and scientific disciplines with updated notion-category apparatus were characterized. We determined the peculiarities of the structural-functional scheme of the touristic sphere (use of the natural and cultural-historical resources - providing touristic services obtaining economic profits). We should note the increasing attention to the ecological problems of tourism geography, balance of the social, ecological, economic components at different levels of territorial organization of the touristic process.

Key words: tourismology, tourism studies, geography of recreational resources, geography of tourism infrastructure, geography of changes in the environment of tourism, geography of touristic movement, country studies for tourism, local studies for tourism

\section{Географія туризму: функціональна структура та роль у туризмознавстві}

\author{
О.Ю. Бордун, П.В. Романів, В.Р. Монастирський
}

Ivan Franko National University of Lviv,Lviv, Ukraine, obordun@ukr.net

Анотація. Об'єктивне підгрунтя туризму як явища суспільного життя робить його складним, багатогранним об'єктом наукового пізнання. Географія була однією з наук, що досліджувала туризм з початку перетворення його у феномен людського буття і започаткувала інноваційний науковий напрям- географію туризму. Простежено теоретичні підходи до визначення сутності поняття географія туризму, туризмознавства і туризмології як інтеграційних понять у науковому дискурсі стосовно вивчення й дослідження туризму. Визначено загальні правові, організаційні, природничі, соціально-економічні, гуманітарні i інші засади географії туризму, що спрямовані на забезпечення динамічного розвитку галузі в цілому. Оцінено сучасні традиції і тенденції європейської школи туризмознавства, новітні наукові напрями в блоці суміжних дисциплін і представлене авторське трактування функціональної структури напряму “Географії туризму”. Визначено інтегральний характер теорії географії туризму 3 його характерними структурними змінами у зв’язку з багатофункціональністю наукових напрямків, оскільки географія туризму складна природо-еколого-соціо-економічна система, яка охоплює географічні, екологічні, соціокультурні, економічні, політичні, організаційно-правові та інші аспекти, процеси і явища, пов'язані з комфортним та безпечним відпочинком і оздоровленням. Охарактеризовано позицію географії туризму у системі наук та наукових дисциплін 3 оновленим понятійно-категоріальним апаратом. Визначено особливості структурно-функціональної схеми туристичної галузі (використання природних та культурно-історичних ресурсів - надання туристичних послуг - отримання економічних прибутків). Акцентується на необхідності збільшення уваги до екологічних проблем географії туризму, збалансованість суспільної, екологічної, економічної складової на різних рівнях територіальної організації туристичного процесу.

Ключові слова: туризмологія, туризмознавство, географія туризму, географія рекреаційних ресурсів, географія туристичної інфраструктури, географія змін туристичного середовища, географія туристичного руху, туристичне краӥнознавство, туристичне краєзнавство 
Introduction. Tourism has a dominating and priority position regarding the vectors of the development of the economy and culture, and is one of the most promising directions of socio-economic development, because it demonstrates stable tempi of growing demand for it. The formation of the new scientific direction - tourism studies - has become a specific response to social demand, urgent need of modern society.

In the scientific literature, the capacity of the terms "tourism geography", "tourism studies", "tourismology", particularly from the systemic perspective, was defined in the works of contemporary Ukrainian scientists (N. Krachylo, 1980, 1987, O. Ljubiceva, 2004, 2006, 2010; M. Malska, 2008; V. Fedorchenko, 2013;) and foreign researchers (V. Alejziak (Alejziak); Р. Батлер (R.W. Butler); P. Bernecker (P. Bernecker), R. Winiarski; W. Gaworecki, I. Zorin, W. Hunzicker, M. Hall (Hall, C. M), A. Kovalchuk, J. Krippendorf (J. Krippendorf), K. Kraft (K. Kraft), W. Kreisel (Kreisel, Werner), O. Lazzarotti (Lazzarotti, Olivier), S. Liszewski, V. Kvartalnov, M. Mironov, V. Preobrazhenskij, D.G. Pearce, P. Risch, J. Stradner and others.

Every year, the amount of specialized scientific journals describing the problem of tourism as a modern phenomenon increases around the world. In 1971-1990, 16 additional journals devoted to the problems of tourismology emerged, and in the period of 1991-2004, the list of journals has enlarged with another 39 positions, and currently Hospitality $\&$ Tourism refers to the list of touristic scientific periodic editions comprising 131 names, which according to the analysis conducted by Cheng C.-K., Li X. R., Petrick J. F. \& O^Leary J. T contain only a comparatively small share of the articles by geographic scientists focusing on the phenomenon of tourism (Cheng, C.-K., Li, X. R., Petrick, J. F., \& O'Leary, J. T., 2011). Among the defences of Candidate of Sciences dissertations, the share specializing in tourism geography is also very small according to the researchby Egyptian scientists Jafari and Aaser (Jafari, J., Aaser D., 1988). However, we consider the geographic approaches to the research most correct for understanding the sustainable (balanced) development of tourism.

Geography is a perfect discipline for the study of the global touristic sphere. There are many principally geographic aspects of tourism orientated to the following principle: touristic product as economic and geographic category is traded and consumed in the place of origin and purpose of tourists, tourism transforms the environment of the visited places by the means different from non-touristic processes, provides transport of people, goods, services, ideas and money through space; provides a special way in which people understand and treat the environment.

Considering the essential spatial aspects of tourism, foreign geographers have made a significant contribution to academic research on tourism. They have developed some key conceptual models for the explanation of the development of tourism, including the morphology of the resort, touristic-historical places and the life cycle of the touristic zone. Moreover, geographers have made an important contribution to the study of ecological dimensions of tourism and the concept of sustainable development of tourism and ecotourism.

Despite the fact that tourism geography is based on the study of tourism, and has also increased the number of students of the Geography Faculty, ironically it occupied a certain peripheral position in academic geography. This status could partly be due to the inertia of the academic institutions and staff, who do not consider tourism a serious subject for study, and also difficulties in assessment of the touristic sphere compared with primary and secondary sectors of the economy.

Therefore, having analyzed foreign and domestic experience of studying geography as an interdisciplinary sphere of knowledge in tourism, we should distinguish the range of the main tasks of our publication: to determine the peculiarities of the system approach to tourism as multi-aspect phenomenon; characterize the structure of tourism studies and tourismology; find and distinguish the place of tourism geography in the system of tourismologic disciplines; describe the relationship of tourism geography and various sciences, disciplines, interdisciplinary scientific problems, determine the directions and the content of such relationships.

Materials and methods. The continuous increase in the amount of travel and qualitative content of such phenomenon as tourism is indicated by the statistical methods developed by the World Tourism Organization (UNWTO). Thus, without analysis of the material by the UNWTO, there would have been no integral, systematic perception of the formation of tourism geography as a fundamental direction in post-classic geography. Integration of the theoretical bases of tourism geography was performed using philosophical methods of dialectics and general scientific methods of analysis, synthesis, induction and deduction.

Results and their analysis. Based on the modern interpretation of tourism as a phenomenon of social life, there occur certain difficulties in the approaches 
at the beginning of its emergence, establishment and further development. However, most researchers agree that its start should be attributed to the introduction into everyday life of a certain number (or category) of people who spend their free time traveling into every-day life. Therefore, the studies of such phenomenon begun with the process of mass, in some way organized, touristic movement.

As noted by the authors Ljubiceva O.O., Malska M.P., Zinko Y.V., tourism geography, perhaps, is one of the first scientific disciplines which have chose tourism as the subject of their research almost since the beginning of its development when it was developing from individual travel to a mass phenomenon, i.e. the XIX century.

The first scientific-practical studies of the touristic process were recorded in European countries such as Austria, Switzerland, Germany, in the late XIX century. At the same time, the touristic glossary was enlarging etymologically with specialized terms and notions. Let us look at the key events and dates at the turn of the XIX-XX centuries in European touristic science and practice (Table 1).

The first half of the XX century witnessed the emergence and work of educational institutions which became the creators, promoters of science and practice of tourism. Such institutions are:

1) Düsseldorf College of Hotel Trade and Transport, 1919

2) Research Institute for Tourism of Berlin College of Trade, 1929;

3) Scientific-Research Institute of Tourism of College of Global Trade in Vienna (now the Vienna University of Economics and Business), 1934;

4) Institute of Tourism Research in Bern and Seminar on Tourism (Seminar für Fremdenverkehr) in St. Gallen in 1941. There, the first fundamental works on tourism by professors W.Hunzicker and K. Kraft were published.

After the WWII, the science of tourism developed further. In Switzerland (Bern) in 1949, the International Association of Scientific Experts in Tourism (AIEST) was founded, which began to publish the Journal "Revue de tourisme". A significant role in the establishment of this institution belongs to the Swiss professor C. Kaspar. Under his influence, the first centers of academic studies for tourism geography emerged in the economically developed countries of Western Europe, which in the process of their scientific work have generalized the national scientific findings. Particularly, the British scientific contribution was summed up in the researches by D. Pearce and R Butler (Pearce, D.G. \& Butler, R.W. 1993), W. Kreisel defined the contribution and scientific condition of the German tourism geography (Kreisel, Werner, 2004.), Oliver Lazzarotti has done the same regarding the French tourism geography (Lazzarotti, Olivier, 2002), and Michael Hall has analyzed the possibilities of cooperation of national European schools of geography and tourism (Hall, 2009, 2013.).

The results of American studies in tourism geography were summarized in the research by K. Meyer-Arendt and A. Lew (Meyer-Arendt, Klaus J., and Alan A. Lew, 2003).

Later, the theory of tourism began to develop in Eastern Europe, where the educational institutions of preparation of responsible specialists appeared. The historical analysis of the establishment of tourism geography conducted by M. Rutynsky (Rutynsky M., 2016) shows the appearance of fundamental researches on tourism geography in Slovenia (monograph by V. Brachich), Bulgaria (M. Bychvarova), Poland (J. Warzynska and A. Jackowski), Russia (P. Zachiniaiev and N. Falkovych, M. Ananiev, E. Kotliarova).

The start for tourism studies in the domestic science was made by several scientific disciplines. The first one was tourism geography. Particularly this scientific direction would further develop and form the basics of the meta-theory of tourism. This is reflected in the general structure of human geography generalized by O. Shabliy, where in the block of disciplines of Economic Geography, the direction Tourism Geography is presented (Shabliy O. I., 2001). As tourism emerged as a social phenomenon, it took a leading place in this structure. Since the mid 1990s, the subject of research in recreational geography was study of geospatial patterns of the human behavior in the process of recreational activity and provision of recreational facilities.

A significant breakthrough in the development of tourism geography in Ukraine was observed between the mid 1990s and the beginning of the XXI century. First of all, it is related to the defense of candidate dissertations by Krachyla M. P., Ljubiceva O. O., Beidyk O. O. and a number of candidate dissertations, as well as the publication of fundamental monographs (Bejdyk, O.O., 2001; Ljubiceva, O.O., 2006), and also regional monograph editions (Fedorchenko V.K., Pazenok V. S., Kruchek O. A. and others., 2013).

In O. O. Bejdyk`s monograph, the methodological basics were systematized and the methods of the research of recreation-touristic resources was elaborated, the knowledge of their structure was enlarged, and the notion-terminological apparatus of recreational geography and tourism geography was deepened. Resource-recreational assessment and passportization 
Table 1 Most notable events of the initial stage of tourism science, particularly tourism geography, at the turn of the XIX-XX centuries.

\begin{tabular}{|l|l|l|l|}
\hline № & \multicolumn{1}{|c|}{ Author } & $\begin{array}{r}\text { Event } \\
\text { (year) }\end{array}$ & \multicolumn{1}{c|}{ Event } \\
\hline 1 & E.Fruler & 1883 & $\begin{array}{l}\text { Report about the development of Swiss hotel management in } \\
\text { Zurich }\end{array}$ \\
\hline 2 & J. Stradner & 1884 & $\begin{array}{l}\text { Report at the Congress on Intensification of Tourist Development } \\
\text { in Austrian provinces in Graz }\end{array}$ \\
\hline 3 & E. Fruler & 1896 & Publication of study "Significance of touristic statistics" \\
\hline 4 & J. Stradner & 1905 & $\begin{array}{l}\text { Term Fremdenverkehrsgeographie emerged - geography of for- } \\
\text { eign tourism (German) }\end{array}$ \\
\hline 5 & J. Stradner & 1917 & $\begin{array}{l}\text { Notions "tourism geography" and "touristic district" were for the } \\
\text { first time used in study "Breakthrough of tourism" }\end{array}$ \\
\hline 6 & K. Spiuts & 1919 & Vienna, Austria. Notion "Touristic industry" was introduced \\
\hline 7 & R. Blanchard & 1924 & Publication of study "Tourism in the French Alps" \\
\hline 8 & A. Marioti & & \\
\hline
\end{tabular}

of administrative-territorial subjects of Ukraine was conducted, and its rating recreational zoning was substantiated.

The monograph of Ljubiceva O. O. (Ljubiceva, 2006) focused on the theory, methodology and methods of the study of geospatial aspects of the development of the market of touristic services, mechanism and patterns of its functioning and territorial organization at different hierarchic levels.

According to O. Ljubiceva, tourism studies was precisely the most theoretically developed interdisciplinary scientific direction which reveals all the complex basic theories of tourism as a social phenomenon (Ljubitseva, 2010).

Tourism studies is a scientific direction within which tourism is studied as social phenomenon (Ljubitseva., 2010). In the collective monograph edited by V. Pazenok, V. Fedorchenko, tourism studies was defined as a notion which covers any knowledge of tourism: general and partial, theoretic and practical, abstract and specific, rational and sensitive, ideal and real (Fedorchenko, Pazenok, Kruchek and others., 2013), and tourismology is interpreted as a meta-theory of tourism based on philosophy of tourism as a phenomenon of nowadays.

The Ukrainian (Fedorchenko V. K., Pazenok V. S., Kruchek O. A. and others., 2013; Krachylo N.P., 1987; Ljubitseva O.O., 2010) and foreign scientists (Alejziak, Winiarski, 2003; Kvartalnov, 2003; Mironenko, Tverdohlebov, 1981; Preobrazhenskij, 1988) in general terms had similar ideas on the division of tourism studies into scientific directions which formed on the boundary of economics, geography, history, philosophy, pedagogy, psychology, and law.

In the novel history of science of tourism, one of the first one to start generalizing the knowledge about tourism asa multi-faceted and multi-aspect phenomenon was Birzhakov M. B. In his study "Introduction to Tourism", he proposed the section "Names of the sciences on tourism" (Birzhakov, 2006). This section contained definitions of the science which deals (will deal with) tourism as a certain system of knowledge concerning this phenomenon. These names are confined to: touristics, tourology, tourography.

Polish researcher V. Alejziak proposed to call the science "touristology", where the main, central, integral object of the research would be the tourist, psychology of the tourist. According to V. Alejziak, "study of tourism as a phenomenon includes interdisciplinary knowledge, multifacetedness, flexibility and variation of forms of participation, similarly to organizational structures and systems of management, extreme increase in the number of travelers and load on the most visited objects (Alejziak, Winiarski, red., 2005)

We think that these notions do not reflect tourism as a systematic phenomenon, because touristics is used as a Polish-borrowed term, tourology and tourography have the term "tour" in common, which does not fully reflect the essence of tourism as a systematic phenomenon. Therefore, definition of "tourism studies", and the science "tourismology" most successfully reflect the phenomenon of tourism, including the subjective-objective component, the study of which requires knowledge of different sciences and disciplines. 


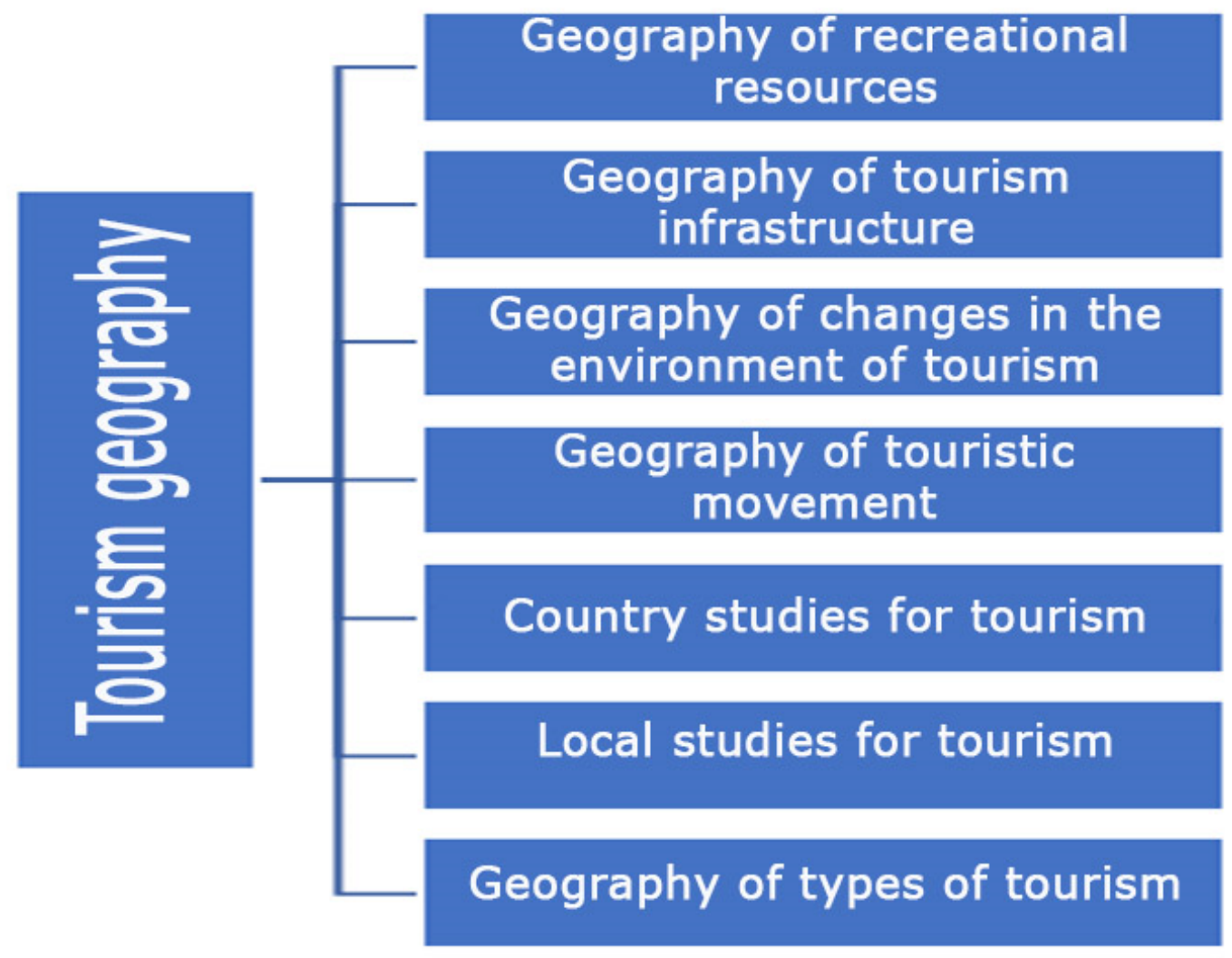

Fig.1 Structure of tourism geography

As with the structure of tourism studies, this problem has a number of propositions and variants. For example, Mironov Y. B. differentiates tourism studies into such directions as: economic, management, geographic, historical, philosophical, psychological, and pedagogical (Mironov, 2018).

Tourism geography was distinguished as a direction from economic geography as a result of convergence with adjacent sciences and has become the basic discipline in the system of tourism studies and tourismology as a result of divergent processes in science.

Tourism geography is one of the first directions in tourism studies, and our research was performed particularly within this branch. Tourism geography has been developed at the same time by domestic and foreign scientists. Because geography as science has been established long time ago and was organically united with travels, then tourism geography is the most developed scientific direction of tourism studies. The main founders of tourism geography in Central-Eastern Europe could be considered the Academic School of Polish professor S. Lishensky, continued by Jackowski, and among the most contemporary researchers $-\mathrm{W}$. Alejziak. Among the Ukrainian researchers of tourism geography, O. Beidyk and O. Ljubiceva should be distinguished. Generalizing the views of Ukrainian and foreign researchers of tourism geography, in its structure, 5-7 separate scientific directions are distinguished (Fig. 1).

The main preconditions for tourism are natural factors which contribute to the active recreation and health improvement of people. It is particularly due to such recreational resources that tourism has developed as a phenomenon. The main goal and the main direction for geographers today is still the geography of recreational resources of tourism.

The post-industrial stage of the development of tourism originated as a new direction in tourism geography - geography of touristic infrastructure. Non-evenness of provision of touristic resources in different parts of the world, regions and districts causes changes in the environment which is exploited by tourists for too long and therefore a new direction emerged - geography of changes in the touristic environment.

Flows of tourists occur between donor countries of tourism and countries which accept them. Particularly the flows of tourists are the subject of geography of touristic movement.

If as the subject we consider the study of countries which have touristic-recreational potential (TRP), then the discipline tourism country studies forms. The studies of local areas for presence of 
TRP are conducted through the discipline of heritage tourism ( tourism studies ). Typological diversity is studied by geography of types of tourism, and the central geographical discipline in this sense is tourism geography.

The place of tourism geography in the system of sciences is determined objectively by the need and scope of goals orientated towards solving the social needs. Tourism geography is a complex naturalecological-socio-economic system dealing with geographical, ecological, socio-cultural, economic, political, organizing-legal and other aspects, processes and phenomena, associated with comfortable and safe recreation and health improvement.

No doubt the basis for tourism geography is formed by natural (geography of natural resources, knowledge on landscape, geoecology, recreationallandscape projecting, specialized natural sciences) and social geographies.

According to the definition by H. Denysyk, "Natural geography is the science which consistently studies the nature of the Earth or its particular regions from their natural condition through history of land use to the current anthropogenic development" (Denysyk, Stefankov, Chyzh, 2018). The leading scientists, L. H. Rudenko, Y. O. Maruniak, I. H. Chervaniov (Rudenko, Maruniak, Chervaniov, 2018) have formed the corresponding concept of the development of national geography on the basis of the paradigm of innovatory development and emphasize the increase in innovatory, informational and pragmatic functions of geography. Researchers O. Topchiev, V. Nudelman, L. Rudenko report on drastic changes in the demands of domestic society regarding the development of the natural-geographic basis for the needs of the regionalizing the country. Geographers have already opposed the geographical determinism which emphasized the direct dependence of society on the natural environment with the concept of possibilism, using which the natural-resource potential of the territory is only a number of opportunities which could be used to different extent (Topchijev, Nudelman, Rudenko, 2012). No doubt, natural geography, by the level of dealing with the natural objects and phenomena, dominates among other sciences in tourism geography, originating another discipline - geography of recreational resources.

However, no less important is social geography that deals with territorial organization of touristic activity, conditions and peculiarities of its development and accommodation, population, culture and also economy in the world in general and in separate regions in particular.
Ukrainian researchers O. I. Shabliy (Shabliy, 2001), Y. B. Oliinyk, A. V. Stepanenko (Oliinyk, Oliinyk, Stepanenko, 2012), M. Pistun (Pistun, 1996; Pistun, 2005) and others express another point of view that social geography is a group of geographical sciences including economic geography, social geography, geography of population, science geography, which fundamentally contribute to the development of tourism geography.

This block also includes the recreational geography represented by such prominent Ukrainian scientists as O. Bejdyl (Bejdyk, 1997; Bejdyk, 2001), O. Ljubiceva (Ljubiceva, 2004, 2006, 2010), P. Masljak (Masljak, 2008), I. Smal (Smal, 2010). Researchers are developing theoretical-methodological bases of the territorial organization of recreation and health improvement, determining and evaluating recreational resources, determining recreational capacity and possible border loads based on the scientifically substantiated standards with the purpose of optimizing the development and functioning of TRS (Ljubiceva,, 2004).

Tourism, especially in the XXI century, is closely associated with the geography of services. The most significant contribution to this direction was made by the domestic researchers M. Malska (Malska, Antonuk, Hanych, 2008), O. Ljubiceva (Ljubiceva, 2004, 2006, 2010) and others. Particularly, the researchers study the functionality and dynamics of the market of services and the mechanisms in the tourist activity regarding transport connections, accommodation, food, and also leisure services.

As society develops, the needs of consumers of touristic services change. The modern day tourist demands much more from the Roman metonymic phrase "Bread and circuses" (Lat. panem et circenses). Meeting the demands of the time, there is currently a new direction in the social geography developing - culture geography. The firstto distinguish this scientific direction and term in Ukrainian geography was S. Rudnytskyi (Rudnytskyi, 1905). Culture geography as a science continues to be studied and its theoretical-methodological basis developed by researchers I. Rovenchak (Rovenchak, 2008), O. Ljubitseva (Ljubitseva, 2010), L. Shevchuk (Shevchuk, 2007). The researchers distinguish territorial and national integrities of culture in the context of geographical environment.

According to V. Gerasymenko, the integral character of the theory of tourism is deepening. Characteristic structural changes occur in the contents of the theory of tourism, because it included many functional scientific directions such as marketing, planning, finances, human resource management, etc 
(Gerasymenko, 2011). Furthermore, today it is hard to imagine integral study of tourism without integrating it into other scientific fields: sociology, psychology, geography, medicine, ecology, history, culturology, etc. Gradually, tourism has taken its place among the subjects of many sciences, which in turn contributed to the enlargement and complication of the subject of its own. Today, tourism could be studied and managed only by mutual efforts of specialists in different scientific spheres. Therefore, some authors consider knowledge of tourism as a universal science which is managed by a number of related sciences and becomes a component of these sciences itself.

Tendencies of rapid development of the touristic industry around the world createthe necessity of quick harmonious interaction, quick response, logistics between all the links of the touristic product. The responsibility for all these processes is imposed on the adjacent sciences. In the system of tourism, the relationships of economics and culture, employment of population, international relations and safety, hotel business, transport organizations, are closely interweaved.

Let us consider in more detail the place of the adjacent sciences in the structural-functional position. We should note the duality of the mutual influences of tourism geography and adjacent sciences.

Because the economy of the tourist business generalizes the economic indicators of touristic activity from economies of certain business entities - natural persons and juridical persons, the economy as science in the context of tourism geography could have two levels:

1) economy of tourism as inter-branch complex of tourist services;

2) economy of subjects of touristic industry.

The system of tourist services is not confined to only commercial (market) relations, they also include fulfillment of social needs, because the main object of tourism is human. The social aspect of market services (social) is satisfaction of needs of people in recreation, travel, maintaining the health and recuperation. This is not the full list of constituents of tourism, an important and constant aspect of which is exploring and educational functions which contribute to the development of socialization, religious, political integration, cross-culture communication. In this we see the mutual influences of social sciences (sociology, political science, law, ethnology and anthropology, etc) and tourism geography, particular international.

Tourism is one of the main forms of international relations and forms (or rather is able to form) favourable international economic and communicative climates. International governmental and institutional touristic cooperation of states effectively develops at bilateral, regional, subregional, interregional and global levels, including within the frameworks of international organizations, international touristic conferences, forums, symposiums and is an effective mechanism of creating a favourable environment for tourism, integration into global touristic processes.

Among the exact sciences (particularly mathematics, computer sciences), the latter is of special significance in the interrelations with tourism geography. Currently, in tourism geography in Ukraine and around the world, great attention is paid to the computerization of the touristic process, use of computer technologies, etc.

Information technologies enhance the processes of globalization and integration of various resources, demand qualitatively new approaches to ecological, legal, economic and information-documentation provision of the organization of data on tourism and geography of touristic activity. In our opinion, in the system of tourism geography, such disciplines should be included which are related to the development and introduction of information technologies which could present trips, travels, tourism in virtual view.

Virtual tourism involves virtual excursions, virtual tours, virtual meetings, where everyday reality is substituted virtually. Predecessors and historical origins of such type of tourism are popular TV-shows which familiarized the viewers with interesting touristic places. Due to the virtual tourism, interesting regions, objects, phenomena, processes become available to the internet users without any great additional costs. Such type of tourism gives advantages, particularly to handicapped people, and also new options for travelers to travel, though they become passive viewers. Virtual trips to notable historic, cultural and architectural monuments and objects of the nature-reserve fund could be seen in many web-pages in the internet, presented as described excursions with numerous photo and video materials. Virtual experience helps to approach the reality. Virtualization also helps in selecting potential touristic destinations which the tourist would visit in real life.

Taking into account the peculiarities of the structural-functional scheme of the touristic sphere (use of natural and cultural-historical resources provision of touristic services - obtaining economic effects), the ecologisation of tourism geography leads to understanding of the processes of balanced public, ecological, economic components at different stages of territorial organization of touristic processes. 
Also tourism geography is directly related to the town-building spheres, especially in the context of development of urban tourism, specifics of its organization, appropriateness of cities and their certain parts for the needs of tourism, recreation, excursion activity.

For tourism geography, particularly in the aspect of information evaluation, geographical patterns of location of resources, etc, historical sciences are important, particularly specific historical disciplines, such as: archeology, genealogy, heraldry, information evaluation, historical demography, heritage studies.

Tourism geography forms its notion-category apparatus at the border with other sciences and disciplines. Of course, as the basis, the notion-category apparatus of tourismology was taken and enlarged. It has to be noted that the dictionary of terms in the sphere of tourism is regularly being enlarged due to rapid development of new directions of market of services. However, as noted by O. Ljubiceva, despite numerous attempts to achieve the integrity of interpretation of even basic terms and notions, definition of the main category, no unanimity has been achieved (Ljubiceva, 2006).

Notion-category apparatus was significantly expanded by O. Beidyk. In tourism geography, new definitions appeared:

recreational agglomeration - interrelated combination of settlements which develop in a certain territory based on the common use of recreational resources and infrastructure (Bejdyk, 1997);

capacities of TRS (Touristic-recreational system) - characteristics (diversity, dynamics, comfort, stability, effectiveness, hierarchization, reliability, etc) (Bejdyk O.O., 1997);

Geoqualimetry - science about assessing the qualities of geosystems, bordering the scientific direction the objective of which is evaluation of natural conditions and resources (Bejdyk, 1997);

Ecological capacity of region, quantitatively expressed ability of natural or natural-economic complex to maintain the necessary social-ecologic balance in certain territory (Bejdyk, 1997).

Currently, the following terminological notions are gaining popularity in tourism geography : country-tourism - ethnographic tourism, one of the types of educational tourism which has become popular in rural areas; canyoning - sport traveling through waterfalls and canyons using speleological equipment and technologies; cultural-information landscape - collection of cultural-information, compactly arranged locations which have sufficient cultural-historical potential for the fulfillment of the cultural and rec- reational needs of people (Bejdyk O.O., 1997). The foregoing geographic-touristic notion-terminological apparatus add to the definitions of adjacent sciences: economic, political, historical, town-building, etc.

With time, these researches form the theoretic bases of tourismology. According to V. A. Kvartalnov, tourismology as science requires:

-integral complex approach to it as a subject of scientific knowledge;

- systematization of already developed basis of the analysis of the development of tourism;

-clear definitions of the objective, subject and object of study;

- determination of frames of factual scientific problematic, uniting its separate components into a general picture;

-generalization of accumulated knowledge and methods of study of geotourism;

- study of the system of interdisciplinary relationships, particularly with such sciences as anthropology, ecology, economics, recrealogy, etc (Kvartalnov, 2003).

Considering the above-mentioned thoughts, we should note that the main methodological functions of tourism studies are integrative, system-forming, and structural-functional. The incompleteness of scientific and practical knowledge of tourism as a multiaspect phenomenon of social life is affirmed by the idea that tourismology is a multi-vector scientific direction which unites philosophical, geographical, legal, sociologic, culturological, pedagogic, and other dimensions awaiting their researchers (Fedorchenko, Pazenok, Kruchek and others., 2013).

Tourism geography has been formed on the conceptual-theoretical fundamental bases of geographical science, particularly nature (theory of nature resource management, landscape studies, geoecology, recreation-landscape planning and other specific natural sciences) and classic social (economic, recreational, culture, services, religion) geographies. However, today tourism geography is expanded by many adjacent functional scientific directions, particularly, the block of economical sciences such as: marketing, planning, finances, management of human resources, etc. Furthermore, in the XXI century, integral knowledge of tourism is impossible without its integration into other scientific spheres: international relations, geopolitics, history, psychology, medicine, culturology, etc.

Conclusions. We have generalized the knowledge and approaches to the understanding of tourism geography, tourism studies and tourismology as integration notions in the scientific discourse regarding study and 
research of tourism as a phenomenon of social life.

The peculiarities of tourism geography as the fundamental discipline of tourism studies, object of scientific knowledge and research, effective sphere of economy, part of fundamental and applied sciences, its structure, and also the methodological functions of tourism geography such as integratory, system-formational, structural-functional ones, were sequentially considered.

The integral character of the theory of tourism with its distinctive structural changes due to the multi- functionality was studied. Special attention was paid to the place of tourism geography in the system of sciences and separate disciplines, relations between them and mutual influences. We outlined the main directions of tourism geography: geography of recreational resources, geography of touristic infrastructure, geography of changes in touristic environment, geography of touristic movement, touristic social studies, local history studies regarding tourism, geography of types of tourism.

We presented the notion-category apparatus of tourism geography, which is regularly expanding due to rapid development of new directions of the market of services, because today new terminological notions are gaining popularity, such as recreational agglomeration, geoqualimetry, cultural-informational landscape, country-tourism, canyoning, touristicrecreational system, etc.

\section{References}

Alejziak, W., Winiarski, R., 2003. Perspektywy rozwoju nauk o turystyce [Perspectives of Tourism Sciences Development]. Nauki o turystyce. Studia i Monografie AWF 7, Kraków. (In polish)

Alejziak, W. \& Winiarski R., red., 2005. Tourism in scientific research, Krakow-Rzeszow.

Beard, L., Scarles, C. \& Tribe, J., 2016. Mess and method: Using ANT in tourism research. Annals of Tourism Research, 60, 97-110.

Bejdyk, O.O., 1997. Slovnyk-dovidnyk z heohrafii turyzmu, rekrealohii ta rekreatsiinoi heohrafii [Dictionary of Tourism, Recreation and Recreational Geography]. Kyiv, Palitra, 130 p. (In Ukrainian).

Bejdyk, O.O., 2001. Rekreacijno-turysts'ki resursy Ukrai'ny: metodologija ta metodyka analizu, terminologija, rajonuvannja [Recreational and tourist resources of Ukraine: methodology and methods of analysis, terminology, zoning]. «Kyi’vs'kyj universytet», Kyiv, 395 (in Ukrainian).

Birzhakov, M.B. 2006. Vvedenye v turyzm: [Introduction to Tourism] $512 \mathrm{p}$.

Butler, Richard., 2004. "Geographical Research on Tourism, Recreation, and Leisure: Origins, Eras, and
Directions." Tourism Geographies 6.2: 143-162.

Cheng, C.-K., Li, X. R., Petrick, J. F., \& O’Leary, J. T., 2011. An examination of tourism journal development. Tourism Management, 32(1), 53-61.

Denysyk, G., Stefankov L., Chyzh O., 2018. Fizychna chy pryrodnycha heohrafiia Ukrainy [Physical or natural geography of Ukraine] Collection of scientific works. Kharkiv. Edition 28. 26-33 (In Ukrainian).

Fedorchenko, V. K., Pazenok V. S., Kruchek O. A. and others., 2013. Tourismology: conceptual foundations of the theory of tourism: monograph, VTS Academy, Kyiv. (In Ukrainian).

Gerasymenko, 2011 Teoriia turyzmu yak skladova turyzmolohii [The theory of tourism as a component of tourismology] Journal of Social and Economic Research, V 2 (42) (In Ukrainian).

Gołembski, red., 2003. Trends of Tourism Research Development.

Hall, C. M., 2013. Framing Tourism Geography: Notes from the Underground. Annals of Tourism Research 43: 601-623.

Hall, C. M., and Page S. J., 2009. Progress in Tourism Management: From the Tourism Geography to Geographies of Tourism, A Review.Tourism Management 30.1: 3-16.

Jafari, J., Aaser D., 1988. Tourism as the Subject of Doctoral Dissertations. Annals of Tourism Research, Vol. 15, p. 413.

Kvartalnov, V.A., 2003. Teoria i praktyka turyzma [Theory and practice of tourism]: A textbook for high schools], Finance and Statistics, Moskwa. (In Russian).

Kowalczyk, Andrzej, 2001. Geografia turuzmu [Tourism geography]. Warszawa: Wydawnictwo Naykowe PWN, 287 p.

Krachylo, N.P., 1987. Geographia turyzma [Tourism geography]. Kiev, Vyshcza szkola, 208 p. (in Russian)

Krachylo, N.P., 1980. Osnovy turismowedenia [Basis of tourism science] Kiev: Vyshcza szkola.,. - 120 p. (in Russian)

Kreisel, Werner, 2004. Geography of Leisure and Tourism Research in the German-speaking World: Three Pillars to Progress. Tourism Geographies 6.2: 163-185.

Lazzarotti, Olivier, 2002. French Tourism Geographies: A Review. Tourism Geographies 4.2: 135-147.

Liszewski, S., Jackowski A., Richling A. (red.), 2008. Powstanie i rozwój geografii turyzmu [Establishment and development of tourism geography] Historia geografii polskiej, Wyd. Nauk. PWN, Warszawa, 206-219. (In Polish)

Ljubiceva, O.O., 2004. Rekreatsiina heohrafiia i rozvytok turyzmu [Recreational Geography and Tourism Development] Collection of Theses of the International Scientific-practical conference on pedagogic and recreational technologies in the modern leisure industry (In Ukrainian).

Ljubiceva, O.O., 2006. Rynok turystychnyh poslug (geoprostorovi aspekty) [Market of tourist services 
(geospatial aspects)]. Altpres, Kyiv, 436 (in Ukrainian).

Ljubitseva, O.O., 2010. Do pytannia terminologi'i v turyzmi [On the issue of Terminology in Tourism] Geography and Tourism, 7-10. (In Ukrainian).

Ljubiceva, O.O., Malska, M. P., Zin'ko Ju.W, 2011. Rozvytok ta transformatsiia predmetnoi sutnosti heohrafichnykh doslidzhen turyzmu // [Development and transformation of the subject matter of geographical studies of tourism] Economic and Social Geography: V. 62. - p. 12-17 (In Ukrainian)

Malska, M. P., Antonuk N. V., Hanych N. V., 2008. Mizhnarodnyi turyzm i sfera posluh [International tourism and services]. Kyiv, Znannia, 886 p. (In Ukrainian).

Masljak,P.O., 2008. Rekreatsiina heohrafiia [Recreational Geography]. Tutorial, Kyiv, Znannia, 343 p. (In Ukrainian).

Mironov,Yu. B. 2018. Turyzmologia jak napr'jam naukovych doslid'zen [Tourismology as the direction of scientific research]. Collection of Theses of the 3rd International Scientific and Practical Conference "Scientific Research in the 3rd Millennium: Social, Legal, Economic and Humanitarian Dimensions" (Kropivnitsky, April 27, 2018) Kropivnitskyj: PVVZ KIDMU. 150153. (In Ukrainian).

Mironenko, N.S., Tverdohlebov I.T., 1981. Rekreacionnaja heohrafija [Recreational Geography]. MSU, Moscow, 207 (in Russian)

Meyer-Arendt, Klaus J., and Alan A. Lew, 2003. Recreation, Tourism and Sport. In Geography in America at the Dawn of the 21st Century. Edited by Gary L. Gaile and Cort J. Willmott, 526-542. Oxford: Oxford University Press.

Napierala, T. \& Wlodarczyk, B. 2018. Komisja Geografii Turyzmu Polskiego Towarzystwa Geograficznego [In book]: Polskie Towarzystwo Geograficzne w setną rocznicę działalności, Tom 3, Historia komisji tematycznych Polskiego Towarzystwa Geograficznego Publisher: Polskie Towarzystwo Geograficzne, Wydział Nauk Geograficznych Uniwersytetu Łódzkiego (In Polish)

Oliinyk, Ya., Oliinyk Ch., Stepanenko A., 2012. Sotsialnyi lokalitet zhyttia osobystostei i terytorialnykh spilnostei. [Social locality of life of individuals and territorial communities]. Ekonomichna ta sotsialna heohrafiia. Vidp. red. Ishchuk S.I. 2 (65). 3-22 (In Ukrainian).

Pearce, D.G. \& Butler, R.W. 1993. Tourism Research: Critiques and Challenges, Routledge, London.

Pistun, M. D., 1996. Osnovy teorii suspilnoi heohrafii [Fundamentals of the theory of social geography]: Tutorial, Kyiv: Vyshcha shkola, (In Ukrainian).

Pistun, M. D., 2005. Pro novi napriamy rozvytku suspilno- heohrafichnykh doslidzhen v Ukraini u 90-ti rr. XX - na pochatku XX1 stolittia [About new directions of development of social-geographical researches in Ukraine in 90th of XX - beginning of XX1 century]. Istoriia ukrainskoi heohrafii.1, 12-15. (In Ukrainian).

Preobrazhenskij, V.S., 1988. Teorija rekreacionnoj heohrafii [Theory of Recreational Geography]. Institut geografy, M., 55 (in Russian).

Rovenchak, I.I., 2008. Heohrafia kultury: problemy teorii, metodolohii ta metodyky doslidzhennia [Geography of culture: problems of theory, methodology and methods of research]: Monograph. - Lviv: LNU named Ivan Franko 240 c. (In Ukrainian).

Rudnytskyi, S., 1905. Nynishna heohrafiia [Current geography]. - Львів,- 34 с. (In Ukrainian).

Rudenko, L.H., Maruniak, Eu.O., Chervaniov, I.H. 2018. Heohrafiia: aktualizatsiia ta tli svitovykh trendiv [«Come on!» Geography: updating toward world trends] Ukrainian Geographical Journal. 2, 1725 (In Ukrainian).

Rutynskyi, M Heohrafiia turyzmu: stan, vektory y aktualni tendentsii rozvytku u XXI stolitti [Tourism geography: the state, vectors and current trends in the XXI century] Visnyk of the Lviv University. Series Geography. 2016. Issue 50. P. 318-336.

Smal, I.V., 2010. Turystychni resursy svitu [Tourism resources of the world]. Nizhyn: Vydavnytstvo Nizhynskoho derzhavnoho universytetu imeni Mykoly Hoholia, 336 p (In Ukrainian).

Shabliy, O. I., 2001. Suspilna heohrafiia: teoriia, istoriia, ukrainoznavchi studii [Social Geography: Theory, History, Ukrainian Studios]. Lviv, Ivan Franko LNU 744. (In Ukrainian).

Shevchuk, L.T., 2007. Sotsialna heohrafiia [Social geography]. Tutorial, Kyiv, Znannia, 350 p. (In Ukrainian).

Topchijev, O.G., 2005. Suspil'no-geografichni doslidzhennja: metodologija, metody, metodyky [Socio-geographical research: methodology, methods, techniques]. Astroprynt, Odesa, 632 (in Ukrainian)

Topchijev, O.G., Nudelman, V. I., Rudenko, L.H., 2012. Heohrafiia pered novitnimy vyklykamy i zapytamy (Ukrainskyi aspekt) [Geography in the face of the latest challenges and questions (Ukrainian aspect)], Ukrainian Geographical Journal, 3-10 (In Ukrainian).

Vlah, M., Kotyk, L., 2018. Teoriia i metodolohiia heohrafichnoi nauky: navch. Posib. [Theory and Methodology of Geographical Science] Lviv, Ivan Franko LNU (In Ukrainian).

Winiarski R., red., 2003, 2004. Tourism Sciences, Krakow, 2 volumes. 